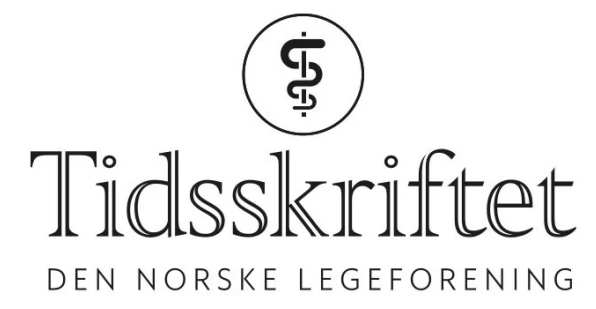

\title{
Et liv som løvetann eller orkidé
}

ESSAY

CHARLOTTE LUNDE

charlottelunde@me.com

«Dette er en fortelling om fremtidshåp, og om barn som er dramatisk ulike med hensyn til hvor sensitive de er for miljøet som omgir dem», lover Thomas Boyce i åpningen av Orkidébarn. Kunnskapen om hvordan oppvekstmiljø former barn, er ekstra aktualisert i en tid der nedstenging har preget samfunnet og presset på den psykiske helsetjenesten for barn og unge øker. 


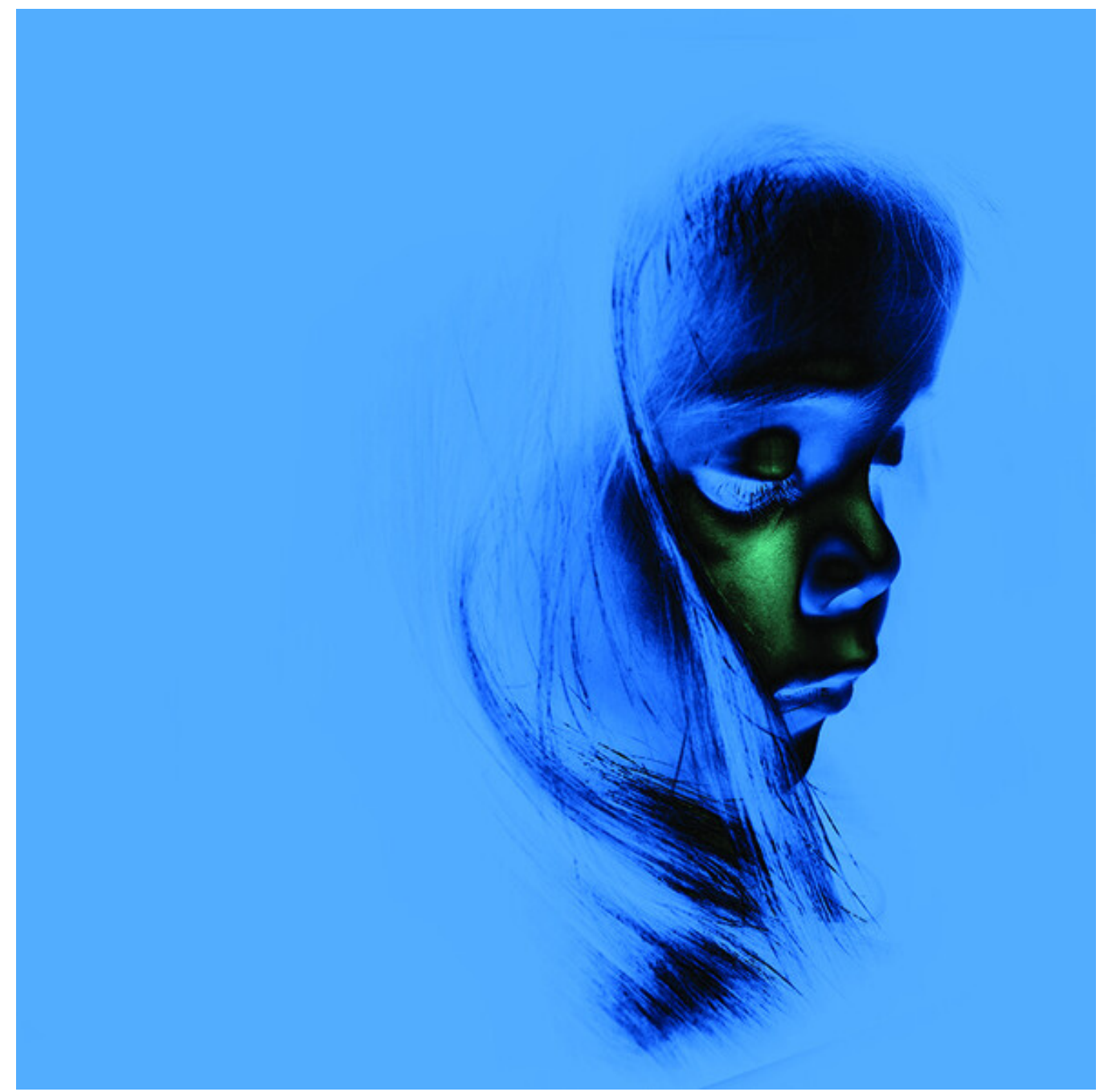

Foto: Umkehrer / iStock. Tilpasset av Tidsskriftet.

Den amerikanske barnelegen og professor emeritus ved University of California San Francisco (USCF) W. Thomas Boyce er en pioner innen pediatrisk forskning. Han har nå skrevet boken Orkidébarn (1) om sin faglige og personlige reise innen det som bredt kan kalles resiliensforskning. Gjennom en omfattende forskerkarriere i over fire tiår har han vært opptatt av å vise hvordan et sosioemosjonelt miljø påvirker barns utvikling både fysisk og psykisk, for å bruke en foreldet dikotomi. For det er nettopp dette Boyce har vært i forskningsfronten med å vise: Kropp og sinn henger så tett sammen at det er meningsløst å snakke om dem som to ulike realiteter. Dette er forskning som bekrefter Engels biopsykososiale modell - og sånn sett burde veilede alt klinisk arbeid med barn og unge.

\section{Det som skjer i barndommen ...}

Tvangssymptomer, uro og nedstemthet er maladaptive reaksjoner som hos mange er blitt forsterket av livssituasjonen under SARS-CoV-2-pandemien. Det sies at psykiatriske diagnoser er øyeblikksbilder, men i dagens helsevesen blir de ofte stående - over lang tid som forklaringer på symptomer og problemadferd. Spørsmålet er om dagens diagnosemanualer alltid er like bærekraftige og hensiktsmessige når vi skal forstå de symptomene og det stresset mange barn og unge opplever som følge av de strenge smitteverntiltakene? 
"Orkidébarn tydeliggjør hvordan ulike miljøbetingelser påvirker et barns

helse og utvikling helt fundamentalt, avhengig av hvilke sårbarheter det

har med seg”

$\emptyset$ kningen vi ser i rapporterte psykiske helseplager hos barn og unge er for mange en direkte reaksjon på de endrede livsbetingelsene pandemien har gitt. Boken Orkidébarn reflekterer ikke direkte over de psykiatriske diagnosene vi bruker på barn, men tydeliggjør hvordan ulike miljøbetingelser påvirker et barns helse og utvikling helt fundamentalt, avhengig av hvilke sårbarheter det har med seg. Slik undertegnede ser det, kan dermed en diagnose som ADHD eller depresjon også bli en del av miljøforståelsen rundt et barn. I noen tilfeller kan dette åpenbart være til viktig hjelp. I andre tilfeller kan det derimot sementere både barnets egen, og omgivelsenes forståelse av barnets utfordring, og heller bli en begrensning.

"Det som skjer i barndommen, blir hos oss hele livet», skriver Boyce og gir oss et større og mer nyansert bilde av hvordan vi kan forstå barns symptomer og særtrekk. Både gjennom forskning og fra erfaring med pårørende, leter han etter et mønster som kan gi en form for svar på hvorfor vi responderer så ulikt på det vi erfarer.

Orkidébarn er ikke bare en bok om barn med en spesiell mottagelighet for miljøet rundt seg, men også en personlig historie om hvorfor Boyce selv endte som forsker i dette feltet. Hans egen søsters ulykkelige liv, som til tross for en oppvekst i samme hjem som han selv, brukes som en parallellfortelling for å illustrere en privat erfaring med et orkidébarn. Mange av oss motiveres av å forstå faglige fenomener ut ifra personlig erfaring.

Boyce beskriver hvordan han opplevde at søsterens følsomhet og introverte personlighetstrekk bidro til et vanskelig samspill mellom henne og moren. Moren på sin side vokste opp med lite emosjonell støtte hjemme og klarte derfor ikke å møte dette behovet hos sin egen datter, tror Boyce. Dette handler ikke om å fordele skyld, men om å forsøke å forstå hvordan dette ble en faktor i søsterens skjevutvikling. Allerede i 11-12årsalderen utviklet hun anoreksi. Vi får vite at hun døde altfor ung etter et strevsomt liv med mange brutte relasjoner. Det beskrives sammensatte årsaker til søsterens skjebne, men Boyce ønsker å vise hvordan han selv og broren sannsynligvis hadde mer «løvetanntrekk» og dermed var mer robuste for den samme familiekonteksten enn søsteren. 


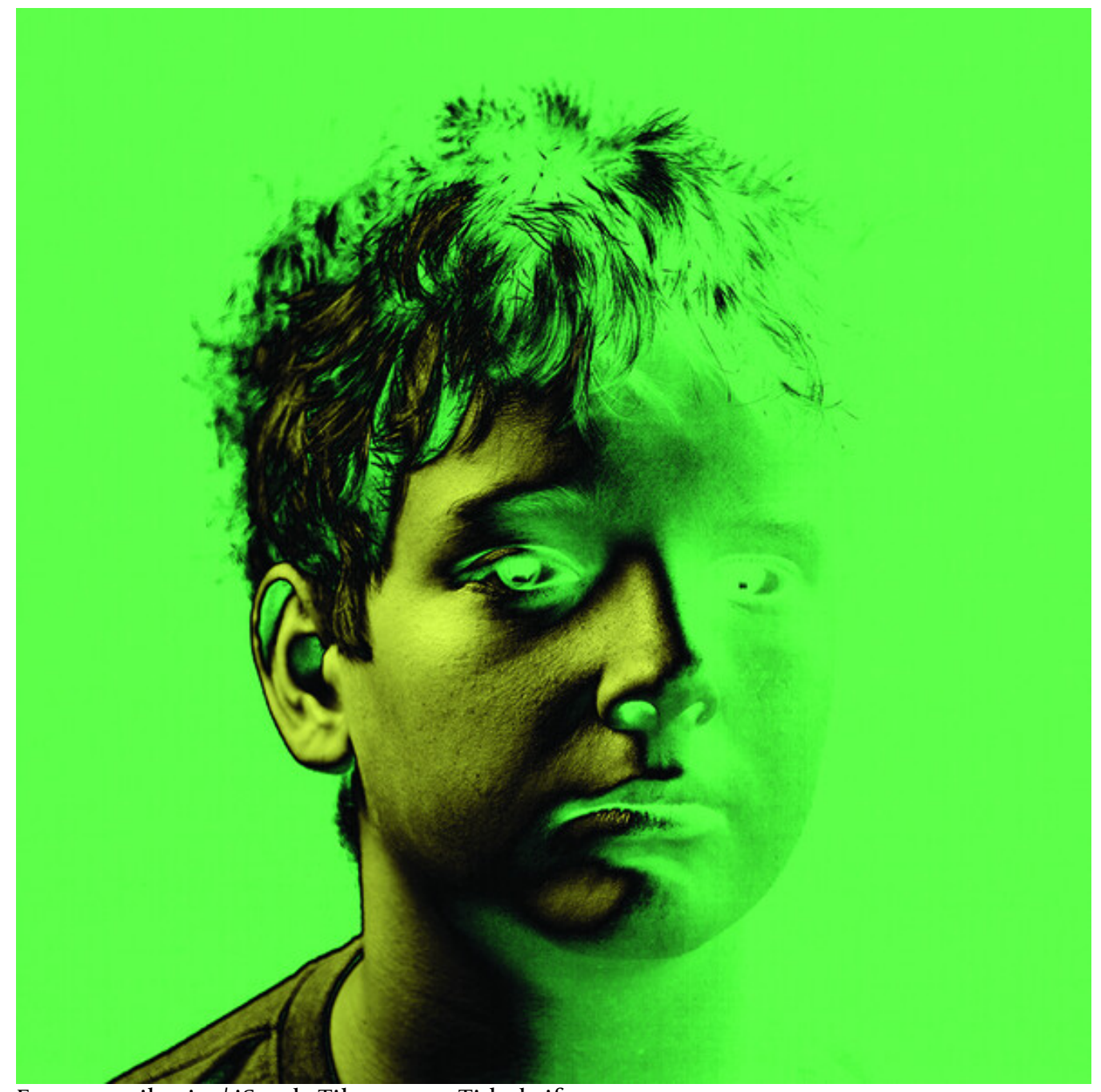

Foto: -art-siberia- / iStock. Tilpasset av Tidsskriftet.

Boyces fortolkning av søsterens liv er åpenbart subjektiv, men det at han tør å være åpen om sin egen familiehistorie, bidrar til å gjøre en komplisert fortelling om epigenetisk forskning og barns utvikling til en lettere tilgjengelig leseropplevelse.

\section{Astma og angst}

Inndelingen i orkidéer og løvetanner kan fremstå som banal, men som Boyce understreker: Det er ikke et enten-eller. Løvetann og orkidé er ikke et forsøk på å kategorisere barn som enten robuste eller sårbare. Det er en kategorifeil på linje med å anta at kropp og sinn representerer to ulike former for virkelighet. De fleste barn er faktisk ganske robuste, men et lite mindretall, eller rundt 20 \% ifølge Boyces forskning, er eksepsjonelt sensitive for den sosiale virkeligheten som omgir dem - sensitive ikke bare for de negative erfaringene, men også for de positive. Det betyr at de vil utvikle seg særlig positivt dersom de vokser opp i et «nærende» fremfor et «tærende» miljø. Denne spesielle reaktiviteten gjør dem mer utsatt for sykdom både i kropp og sinn, men omvendt kan de være desto mer robuste og ressurssterke dersom de făr en trygg og god oppvekst.

Gjennom nevrobiologiske mekanismer viser han til at de mest stressfølsomme barna, orkidébarna, er mer disponerte for alle typer sykdom. De trenger vår oppmerksomhet fordi de langt oftere havner på legekontoret, enten det er med astma eller angst. Boyce viser til at rundt $15-20$ \% av barnepopulasjonen står for mer enn halvparten av all bruk av helsetjenester $(\underline{1}, \underline{2})$. Det er denne ulikheten i helserisiko Boyce ønsker at vi skal forstå mer av, og som er hans vitenskapelige prosjekt å undersøke nærmere. Målet er å kunne forebygge og gi bedre tilpasset hjelp til disse barna enn det vi gjør i dag. 
Stengte skoler og studiesteder, helsesøstre og sosialarbeidere som er blitt omdirigert til å drive med smittesporing og vaksinering fremfor forebyggende helsearbeid, har vært situasjonen i Norge det siste året. Det er dessverre grunn til å frykte at skolens læringspress ikke vil bli mindre når elevene nå endelig vender tilbake til skolen igjen. Det er derfor viktig å påpeke at sammenhengen mellom ung uførhet og manglende fullført skole og utdanning - for mange ensbetydende med opplevelsen av manglende mestring og dårlig trivsel - er godt dokumentert (3-5). Kanskje bør lærestedene akkurat nå virkelig satse på elevenes trivsel og sosiale ferdigheter fremfor akademiske læringsmål? Hvis ikke kan det være en reell fare for at pandemien vil kunne forsterke tendensen til at manglende mestring blir til psykiske helseplager og ung uførhet.

\section{Hjerterytme og omsorgsstil}

Sosioøkonomiske forhold er ofte avgjørende for utvikling og helse. Jo lavere sosioøkonomisk status du vokser opp med, jo høyere risiko har du for både somatisk og psykiatrisk sykdom. Det har vært vanlig å tenke på dette som en slags sosial «arv» der ytre miljøbetingelser bidrar mest. Det er selvfølgelig mer komplekst enn som så. Boyce og flere med han har gjennom en årrekke demonstrert at vår nevrobiologiske respons på miljøet vi vokser opp i har stor variasjon. Hypotesen om såkalt differential susceptibility, eller ulik mottagelighet, innebærer at barn med høy responsivitet er mer adaptive og derfor vil ha ekstra godt av en trygg oppvekst. De vil altså kunne «blomstre» enda mer enn sine mindre sensitive og mer «hardføre» venner. 


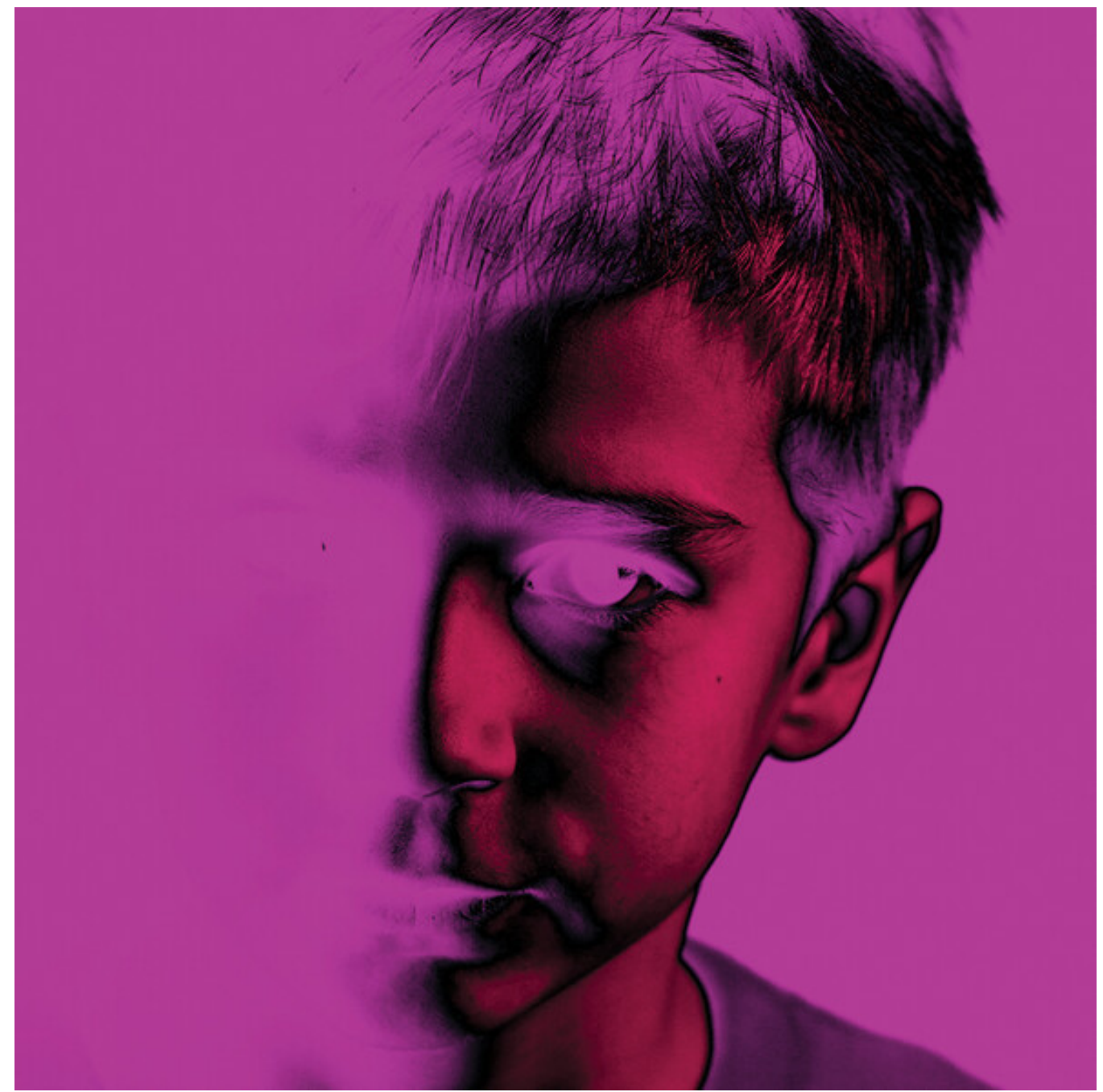

Foto: Asahiphotographers / iStock. Tilpasset av Tidsskriftet.

Men jo mer mottagelig du er, jo mer skadelig kan også et utrygt oppvekstmiljø, manglende mestring i skolen og en negativ selvforståelse bli. Boyce har, blant annet sammen med sentrale forskere som Bruce Ellis, Jay Belsky og Marian Bakermans-Kranenburg, vært med på å vise at de mest potente effektene på helse og utvikling er de som handler om interaksjonene mellom gener og miljøeksponering $(\underline{6})$. Kandidatgener knyttet til nevrotransmisjon har vært spesielt studert, og en mye sitert artikkel viste blant annet at en variant av dopaminreseptoren DRD4 er forbundet med uttalte adferdsvansker og aggresjon hos førskolebarn som vokser opp i et lite sensitivt omsorgsmiljø (7.). I andre studier har man sett på en biologisk markør som hjerterytmevariasjon for å kunne måle sårbarhet hos småbarn. Man fant i en eksperimentell studie utført blant fattige familier at økt hjertefrekvens hos babyer kan predikere barnas adferd 17 måneder senere, avhengig av foreldres omsorgsstil (무).

"Jo mer mottagelig du er, jo mer skadelig kan et utrygt oppvekstmiljø, manglende mestring i skolen og en negativ selvforståelse bli»

Alle har vi noen medfødte trekk som påvirker vårt aktivitetsnivå, vår emosjonelle sensitivitet og vår evne til å regulere stress. For noen kan et mer «ekstremt» temperament på en eller flere av disse dimensjonene utvikle seg til dysfunksjonelle mønstre i samspill med omgivelsene - også uten omsorgssvikt. For de såkalte orkidébarna vil de negative effektene av en utfordrende oppvekst kunne bli desto mer katastrofale, mens de positive effektene vil kunne være like potente dersom miljøbetingelsene er de rette.

\section{En tverrfaglig utfordring}


Så hvordan skal vi som behandlere bedre kjenne igjen disse barna slik at vi kan bruke det klinisk, forebygge sykdom og tidlig kunne tenke utviklingsstøttende tiltak til denne utsatte gruppen? Boyce har ikke ett svar med to streker under. Disse orkidébarna, slik som Boyces egen søster, kan få en negativ utvikling selv om de tilsynelatende har en «normalt» omsorgsfull oppvekst. Han beskriver sin egen søster som kreativ, sensitiv og introvert, men at hun hadde særtrekk som ga henne et annet omsorgsbehov enn han selv og broren hadde.

Gjennom studier både på dyr og mennesker beskriver Boyce hvordan noen barn ser ut til å ha adferdsmønstre med lite adapative trekk. De kan ha en tendens til negative emosjonelle responser på utfordrende situasjoner som kan settes i sammenheng med det han kaller orkidéer. Disse adferdstrekkene er ikke nok til å kunne avgjøre hvorvidt et barn er mer sårbart for stressende livserfaringer enn andre, men Boyce indikerer likevel at noen studier kan tyde på at akkurat dette kan gjelde for flere av dem. 


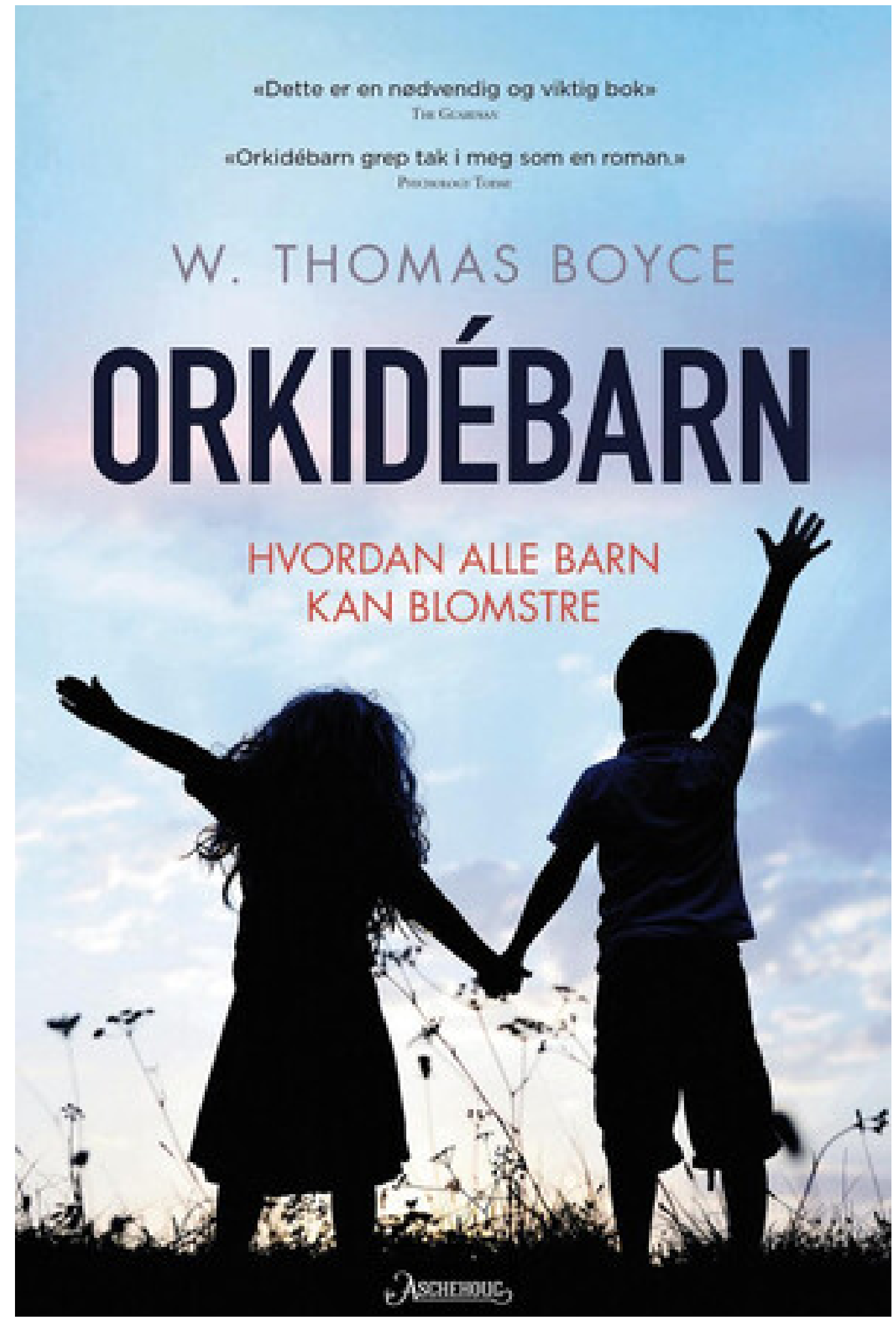

Aktuell bok: W. Thomas Boyce. Orkidébarn og hvordan alle barn kan blomstre. Oslo: Aschehoug, 2019

Negative emosjonelle responser hos barn viser seg likevel på mange ulike måter. Noen barn reagerer på utrygghet med uro og hyperaktivitet. Andre trekker seg tilbake og isolerer seg. Dette kan altså komme til uttrykk både som eksternaliserende og internaliserende adferd, eller som Boyces forskning viser: som hyppige luftveisinfeksjon og magesmerter. Som klinikere møter vi disse barna like gjerne på fastlegekontoret, som i barnepsykiatrien eller i pediatrien.

Slik jeg leser Boyce har han en oppfatning av at medisinen alene ikke kan løse disse utfordringene, men at disse problemstillingene krever en mer helhetlig tilnærming. Han tar oss med på en studiereise innenfor sosial epidemiologi, evolusjonspsykologi og klinisk 
medisin for å underbygge sitt poeng. Vi får blant annet et fascinerende innblikk i hans forskning på rhesusapeunger sammen med adferdsbiologen Stephen Suomi. Suomi er kjent for sitt samarbeid med psykologen Harry Harlow (1905-81) og apestudier på tilknytning mellom mor og barn.

Harlows berømte eksperimenter der nyfødte rhesusaper ble tatt fra mødrene sine (9.), er blitt stående som en bekreftelse på at vi alle har et biologisk tilknytningsbehov. Hypotesen var at apeungene ville velge mat framfor fysisk omsorg og trygghet. Resultatet viste det motsatte. Den sentrale barnepsykiateren John Bowlby (1907-90) var også opptatt av Harlows forskning $(\underline{10})$. Forskingseksperimentet viste at apeungene foretrakk samvær med en «apemor» satt sammen av ståltråd og myk pels fremfor en «mor» av ståltråd som bare ga dem mat. Thomas Boyces forskning står dermed i en naturlig linje til Harlows historiske eksperimenter og Bowlbys tilknytningsteori. I de årene Boyce jobbet i «apelabben» sammen med Suomi fant også Boyce at sosiale stressfaktorer var relatert til sykdom og avvikende adferdstrekk hos de små apeungene.

\section{Håp for fremtiden}

En videreutvikling av kunnskapen Thomas Boyce og andre forskere i dette feltet har lagt grunnlaget for, vil forhåpentligvis kunne bidra til en bedre seleksjon av de barna som har et ekstra behov for forebyggende helsetiltak. Det er altså her Thomas Boyces håp for fremtiden ligger. Hans personlige perspektiv gir boken en sympatisk og engasjert stemme selv om den språklig tidvis kan tippe litt over i klisjépregede metaforer som «tandre orkidéer» og konklusjoner av typen «alle barn kan blomstre».

\section{"Kunnskapen vil forhåpentligvis kunne bidra til en bedre seleksjon av de} barna som har et ekstra behov for forebyggende helsetiltak»

Når Boyce avslutningsvis peker tilbake på åpningen og at boken også er en fortelling om håp, maler han med visjonær pensel når han spør: «Ville det være mulig å lære opp foreldre, lærere og leger i hvordan de kan legge til rette for mer omsorgsfulle miljøer som understøtter barns læring, utvikling og helse?».

Flere av tiltakene han foreslår, er etter undertegnedes oppfatning forebyggende helsepolitikk på sitt beste. Kunne for eksempel skoler og universiteter i større grad vektlagt trivsel og sosial utvikling fremfor kognitive og akademiske ferdigheter hos en kommende generasjon? Læringspress har i lang tid vært en kjent faktor for barn og unges psykiske helseplager (11), lenge før koronapandemien.

I tiden som kommer bør vi etter min, og flere fagfolks oppfatning (1ㅡ), være minst like opptatt av barns trivsel, evne til samarbeid og motivasjon til å lære fremfor prestasjonsnivået på barnas skrive- og regneferdigheter. I Boyces håp for fremtiden ligger det blant annet at en dypere innsikt i de sammensatte årsakene til uhelse hos barn vil kunne gi oss bedre forebyggende tjenester. For selv om kunnskapen om betydningen av traumer og psykososialt stress hos barn øker, skorter det fremdeles på gode kunnskapsbaserte metoder for hvordan vi bedre kan ivareta livslang helse, trivsel og lærelyst hos de yngste blant oss. En bedre innsikt i hvordan vi kan legge til rette for dette, ville ikke bare tjent de sensitive barna spesielt, men oss alle generelt.

\section{LITTERATUR}

1. Thomas Boyce TW. Orkidébarn og hvordan alle barn kan blomstre. Oslo: Aschehoug, 2019.

2. Cassel J. The contribution of the social environment to host resistance: the Fourth Wade Hampton Frost Lecture. Am J Epidemiol 1976; 104: 107-23. [PubMed][CrossRef] 
3. Helle V. Antallet unge uføre fortsetter å øke. Norwegian Research Center (NORCE) 25.8.2020. https://www.norceresearch.no/nyheter/antallet-unge-ufore-fortsetter-a-oke Lest 29.6.2021.

4. Normann TM. Flere unge uføre. Statistisk sentralbyrå 5.7.2019. https://www.ssb.no/sosiale-forholdog-kriminalitet/artikler-og-publikasjoner/flere-unge-ufore Lest 29.6.2021.

5. Wisløff H. Ensomhet på ungdomsskolen gir trøbbel i arbeidslivet. Aftenposten 8.11.2012. https://www.aftenposten.no/norge/i/gPeAL/ensomhet-paa-ungdomsskolen-gir-troebbel-i-arbeidslivet Lest 29.6.2021.

6. Ellis BJ, Boyce WT, Belsky J et al. Differential susceptibility to the environment: an evolutionaryneurodevelopmental theory. Dev Psychopathol 2011; 23: 7-28. [PubMed][CrossRef]

7. Bakermans-Kranenburg MJ, van Ijzendoorn MH. Gene-environment interaction of the dopamine D4 receptor (DRD4) and observed maternal insensitivity predicting externalizing behavior in preschoolers. Dev Psychobiol 2006; 48: 406-9. [PubMed][CrossRef]

8. Conradt E, Measelle J, Ablow JC. Poverty, problem behavior, and promise: differential susceptibility among infants reared in poverty. Psychol Sci 2013; 24: 235-42. [PubMed][CrossRef]

9. Harlow HF, Dodsworth RO, Harlow MK. Total social isolation in monkeys. Proc Natl Acad Sci U S A 1965; 54: 90-7. [PubMed][CrossRef]

10. van der Horst FCP, Leroy HA, van der Veer R. "When strangers meet": John Bowlby and Harry Harlow on attachment behavior. Integr Psychol Behav Sci 2008; 42:370-88. [PubMed][CrossRef]

11. Ungdata. Stress. press og psykiske plager blant ungdom. https://www.ungdata.no/stress-press-ogpsykiske-plager-blant-unge/ Lest 29.6.2021.

12. Ertesvåg F. Eksperter på barnehjernen: Ikke stress med å ta igjen tapt læring. VG 9.5.2021.

https://www.vg.no/nyheter/innenriks/i/oK8PzJ/eksperter-paa-barnehjernen-ikke-stress-med-aa-taigjen-tapt-laering Lest 29.6.2021.

Publisert: 27. september 2021. Tidsskr Nor Legeforen. DOI: 10.4045/tidsskr.20.0859

Mottatt 28.10.2020, første revisjon innsendt 29.6.2021, godkjent 9.7.2021.

(C) Tidsskrift for Den norske legeforening 2023. Lastet ned fra tidsskriftet.no 26. april 2023. 